\title{
Treatment Optimization for Brain Metastasis from Anaplastic Lymphoma Kinase Rearrangement Non-Small-Cell Lung Cancer
}

\author{
Wenhui Wang ${ }^{\mathrm{a}}$ Xin Sun $^{\mathrm{b}}$ Zhouguang Hui ${ }^{\mathrm{b}, \mathrm{c}}$

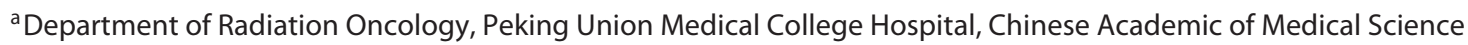 \\ and Peking Union Medical College, Beijing, China; ${ }^{\circ}$ Department of Radiation Oncology, National Cancer Center/ \\ National Clinical Research Center for Cancer, Cancer Hospital, Chinese Academic of Medical Science and Peking \\ Union Medical College, Beijing, China; ' Department of VIP Medical Services, National Cancer Center/National \\ Clinical Research Center for Cancer, Cancer Hospital, Chinese Academic of Medical Science and Peking Union \\ Medical College, Beijing, China
}

\section{Keywords}

Non-small-cell lung cancer · Brain metastasis · Anaplastic lymphoma kinase $\cdot$ Tyrosine kinase inhibitor $\cdot$ Radiation therapy

\section{Abstract}

Background: Brain metastasis is common in non-small-cell lung cancer (NSCLC) with driver gene mutations. Anaplastic lymphoma kinase $(A L K)$ gene rearrangement is one of the common driver mutations in NSCLC. Tyrosine kinase inhibitor (TKI) has been the research hotspot at present. However, there are relatively few studies specified on the treatment of brain metastasis from $A L K$ gene rearrangement NSCLC. The prognosis of these patients, the role of $A L K-T K I$, and the proper combination model of $A L K$-TKI with radiotherapy are worth further exploring. This review focuses on new data on the prognosis of $A L K$-TKI and the proper combination model of $A L K$-TKI with radiotherapy. Summary: According to some retrospective trials, for $A L K$ i-naïve $A L K$ rearrangement NSCLC patients with brain metastasis, crizotinib together with radiotherapy seem to improve intracranial control rate, progression-free survival, and very likely improve overall survival; next-generation $A L K$-TKIs are now replacing crizotinib as first-line treatment. For patients with central nervous system progression during crizotinib application, combining radiotherapy could improve the local control rate while continuing crizotinib to control systemic disease. Second-/thirdgeneration $A L K$ inhibitors had higher intracranial ORR and
DCR even after crizotinib-refractory situations, and they alone had a strong efficacy against intracranial tumors, in which situation radiotherapy might be omitted. Stereotactic radiosurgery (SRS) and whole-brain radiotherapy (WBRT) were both local treatment options for brain metastasis, and the preferred choice was hard to make. ALK resistance is complicated with a wide range of molecular changes, and future studies are needed to solve these problems. Anyway, further and larger prospective studied are worth exploring to offer a confirmed preferred choice of drugs and radiation. Key Messages: Next-generation $A L K$-TKIs are now replacing crizotinib as first-line treatment in ALKi-naïve $A L K$ rearrangement NSCLC patients with brain metastasis, and they alone might have a strong efficacy against intracranial tumors in crizotinib-refractory situations in which occasion radiotherapy might be omitted. SRS and WBRT are both local treatment options for brain metastasis.

(C) 2019 The Author(s)

Published by S. Karger AG, Basel

\section{Introduction}

There are varieties of genomic changes in non-smallcell lung cancer (NSCLC). About $2-7 \%$ of the NSCLC patients show anaplastic lymphoma kinase $(A L K)$ gene rearrangement [1]. Compared with NSCLC without $A L K$ rearrangement, $A L K$-positive NSCLC features more advanced-stage and more metastasis lesions of which the brain is the most common site of metastasis and tumor 
progression $[2,3]$. Treatment of brain metastasis (BM) from $A L K$ rearrangement NSCLC mainly includes the following two aspects: one is systemic therapy, such as target therapy and chemotherapy; the other is local treatment, such as whole-brain radiotherapy (WBRT), stereotactic radiosurgery (SRS), and surgical resection. However, there is no defined recommendations for therapeutic options of $A L K$ rearrangement NSCLC with BM nowadays. Moreover, the selection, combination, and sequence of the different treatment options always depend on the timing, severity of BM, and economic factors. Till now, there are no large-scaled researches on the impact of the different treatment modes on disease control and overall survival (OS).

General Introduction of BM and ALK-Tyrosine Kinase Inhibitor in ALK Rearrangement NSCLC

\section{Incidence and Prognosis of BM from ALK \\ Rearrangement NSCLC}

The incidence of BM ranges from 20 to $30 \%$ in newly diagnosed NSCLC patients with ALK rearrangement, which is similar to unselected advanced-staged patients [1]. With the application of $A L K$-tyrosine kinase inhibitor ( $A L K$-TKI, $A L K \mathrm{i}$ ) in clinical practice, OS of $A L K$ positive NSCLC patients is significantly prolonged [2]. Consequently, the incidence of $\mathrm{BM}$ significantly increased over time in patients with $A L K$ rearrangement. A retrospective study indicated that the cumulative $B M$ rate in $A L K$-positive NSCLC patients was $45.5 \%$ at 2 years, and $58.4 \%$ at 3 years [3]. Another study found that $40 \%$ of the $A L K$-positive NSCLC patients showed evidence of progressive BM when they died [4]. The most common clinical manifestations of $\mathrm{BM}$ were fatigue (39\%), shortness of breath (38\%), nausea and vomiting (33.3\%), and headache (23.9\%) [5]. In addition, the rate of nervous system-related symptoms was as high as $36-$ $82 \%[6,7]$.

The natural course of lung cancer patients with brain metastases is only 3 months. Due to poor penetration of chemotherapeutic drugs, approximately one-third of the patients with advanced $A L K$ rearrangement NSCLC after failure of at least one prior systemic therapy have brain metastases [8], and its prognosis is still worse. The GPA scoring system, established on the basis of the patient's age, KPS score, extracranial metastasis, and number of brain lesions, was proposed by Sperduto et al. $[9,10]$ to predict prognosis of NSCLC patients with BM, and results show an estimated 14.8 months of OS for patients with a high GPA score. Targeted therapy has become an important treatment option for patients with $A L K$-positive arrangement. $A L K$ inhibitors are small molecular drugs, which can treat brain metastases through the blood-brain barrier. Therefore, targeted therapy has a good therapeutic effect on brain metastases. The study by Johung et al. [4] concluded that the median OS of $A L K$ positive NSCLC patients with BM was 49.5 months on condition of ALKi-targeted therapy and radiotherapy. Later, Sperduto et al. [2] put epidermal growth factor receptor (EGFR) and ALK gene changes into the GPA scoring system and established a new Lung-mol GPA scoring system. The median OS of high-score patients in the new Lung-mol GPA scoring system could reach up to 46.8 months. Anyway, drug resistance will eventually occur, and treatment options are hard to make. Till now, there is not much evidence of prospective randomized controlled clinical trials on how to choose targeted drugs and radiotherapy for $A L K$-positive brain metastases. In this review, we summarize some retrospective studies and extract related information in some prospective randomized controlled clinical trials to conclude a better choice of treatment.

\section{Introduction on ALK-TKI's Efficacy on BM in ALK Rearrangement NSCLC}

Crizotinib, inhibiting $A L K, M e t$, and Ros1, was the first generation $A L K$-TKI approved by Food and Drug Administration (FDA) and European Medicine Agency (EMA) and was recommended as the first-line treatment for stage IV lung cancer with $A L K$ rearrangement or Ros 1 mutation $[11,12]$. A pooled analysis of the PROFILE 1005 and 1007 trials showed that [8] among 109 BM patients with administration of crizotinib, the intracranial (IC)-objective response rate (ORR; complete response $[\mathrm{CR}]+$ partial response $[\mathrm{PR}])$ reached $18 \%$, the disease control rate $(\mathrm{DCR} ; \mathrm{CR}+\mathrm{PR}+\mathrm{SD})$ at 12 weeks reached $56 \%$, and the duration of response (DOR) was 26.4 weeks.

Second-generation $A L K$-TKI (including ceritinib, alectinib, and brigatinib) and the third-generation $A L K$ TKI (lorlatinib) are now showing great efficacy in BM treatment. Ceritinib, targeting $A L K, R O S 1$, and IGF1 (insulin-like growth factor 1 receptor kinases), was evaluated in the "ASCEND" clinical trial programs, in which it demonstrated IC-ORR of $35-73 \%$, IC-DCR of $61-$ $86 \%$, and IC-DOR of 8-11 months in either ALK-TKInaïve and $A L K$-TKI-pretreated patients [13-16]. Alectinib, targeting $A L K, R E T$, and ROS1, showing an ICORR of $54-81 \%$, IC-DCR of $78-90 \%$, and IC-DOR of 10.8 to NR (not reached) months in series of randomized trials [17-20]. Brigatinib, targeting ALK and ROS1, in the ALAT trial also showed an interesting activity in the CNS, with an IC-ORR of $42-73 \%$ and an IC- DCR of $83-93 \%$ [21]. Lorlatinib, an extremely selective $A L K$ TKI with activity also against ROS1 kinase, has demonstrated high CNS penetrance in preclinical models and an IC-ORR of $39 \%$. 


\section{Therapy for ALKi-Naïve Patients with BM}

\section{First-Generation ALK Inhibitor (Crizotinib)}

Many studies have shown that $A L K$ inhibitors have therapeutic effects on $A L K$-positive NSCLC patients [2224]. The PROFILE series confirmed a strong anti-tumor efficacy of crizotinib in stage IV ALK-positive NSCLC patients, with an ORR of $59.8-74 \%$ and a median progression-free survival (PFS) of 7.7-10.9 months [25, 26]. Compared with chemotherapy, crizotinib significantly improved ORR, quality of life, and prolonged PFS in patients with or without BM at baseline [26].

However, the efficacy of crizotinib in IC lesions was worse than in extracranial lesions. The central nervous system (CNS) was detected as the first site of tumor progression in up to $50 \%$ of the patients treated with crizotinib [27]. A retrospective analysis of the PROFILE 1005 and 1007 trials showed that [8], with use of crizotinib, ORR (18 vs. 53\%), DOR (26.4 vs. 47.9 weeks), and median time-to-tumor progression (7.0 vs. 12.5 months) were all lower in IC lesions than in extracranial lesions. Moreover, the eventual brain progression rate was far lower (20 vs. $72 \%$ ) in patients without BM than patients showing $\mathrm{BM}$ at the initiation of medication. A similar conclusion was drawn in a study enrolling 59 NSCLC patients with $A L K$ rearrangement by Yoshida et al. [28]. The ORR of crizotinib was $66 \%$ for systemic control and only $20 \%$ for the IC lesions. The rate of brain lesion progression was lower (58 vs. $31 \%$ ) in patients without BM than in patients with $\mathrm{BM}$ at baseline. In conclusion, the anti-BM effect of crizotinib on ALK-positive NSCLC was far from satisfaction. Other local treatment options might need to be combined to improve therapeutic activities.

\section{Combination of Crizotinib and Radiotherapy}

Radiotherapy was considered to be the main local treatment option for NSCLC with BM. However, the efficacy of WBRT was not encouraging. In a study of patients with $A L K$ rearrangement, the ORR of brain radiation on the basis of chemotherapy was only 9.5\% (CR: 4.8, PR: 4.8), and the median PFS for radiotherapy and chemotherapy was only 6.7 months [16].

Combination of brain radiotherapy and crizotinib significantly improved the prognosis of BM patients with ALK rearrangement. Costa et al. [8] found that, compared with crizotinib alone, adding radiotherapy significantly increased ORR (18 vs. 33\%) and prolonged the median time-to-tumor progression (7 vs. 13.2 months) of IC lesions. Other studies also indicated that PFS was significantly increased in patients receiving radiotherapy and targeted therapy to as long as 7 or even 27 months, while only 3-4 months after crizotinib alone $[28,29]$. In addition, the combined application of brain radiotherapy and crizotinib was a good prognostic factor for PFS [28, 29]. Anyway, these studies were all retrospective and not controlled; further prospective trials were needed. Therefore, combining crizotinib and radiotherapy should be carefully assessed clinically.

However, the sequence of targeted therapy and radiotherapy is not clear currently. A number of studies based on EGFR-mutated NSCLC suggested radiotherapy followed by EGFR inhibitors could increase tumor response to TKI, so as to improve prognosis $[30,31]$, which might be explained by the destruction of the blood-brain barrier induced by radiotherapy. Metro et al. [32] quantified the ratio of crizotinib concentration in the cerebrospinal fluid and in the plasma in NSCLC patients with ALK rearrangement. The values were 0.0006 in patients not receiving radiotherapy, and 0.001 in patients receiving radiotherapy before crizotinib. Similar results were also concluded in animal models [33]. As ALK inhibitors and EGFR inhibitors shared a similar anti-tumor mechanism, based on case reports $[34,35]$, it was generally believed that the administration of radiotherapy before or simultaneously with crizotinib could impair the bloodbrain barrier, destroy glycoproteins that function as a drug efflux pump and thus increase the concentration of crizotinib in CNS, eventually significantly improve the therapeutic effect of targeted therapy for IC metastasis lesions.

\section{Second-/Third-Generation (Next-Generation) ALK Inhibitors}

At present, there are a few studies exploring the effect of the second-generation $A L K$-TKI (including ceritinib, alectinib, and brigatinib) and the third-generation $A L K$-TKI (lorlatinib) in $A L K$ i-naïve patients with BM (Table 1). In the Ascend-1 study [14], 19 BM patients without $A L K$-TKI treatment were enrolled, and the results showed that the ORR of ceritinib on IC measurable lesions reached up to $62.5 \%$, and efficacy lasted for 8.2 months. Subgroup analysis in the Ascend-3 and Ascend-4 studies [16] also proved the strong anti-tumor effect of ceritinib on BM lesions. In the ALEX study, Peters et al. [20] compared the efficacy of alectinib and crizotinib on BM lesions from ALKi-naïve NSCLC patients. The results indicated that the ORR (81 vs. $50 \%$ ), CR ( 38 vs. $5 \%$ ), and DOR (17.3 vs. 5.5 months) of alectinib were all higher than those of crizotinib. Besides, for patients without $\mathrm{BM}$ at the initiation of targeted therapy, the cumulative BM rate at 12 months of treatment was lower (4.6 vs. $31.5 \%$ ) in patients receiving alectinib than in those receiving crizotinib. As to the third-generation $A L K$ inhibitor lorlatinib, Solomon et al. [26] found that the CR rate for brain lesions was 25\%. In recent years, the NCCN Panel recommended the second-generation $A L K$ inhibitor alectinib as the first-line 
Table 1. Efficacy of ALK inhibitors for BM in patients with $A L K+$ NSCLC

\begin{tabular}{|c|c|c|c|c|c|c|c|c|c|c|c|c|}
\hline & \multirow[t]{2}{*}{ Drug } & \multirow[t]{2}{*}{ Target } & \multirow[t]{2}{*}{ Trial } & \multirow{2}{*}{$\begin{array}{l}\text { Line } \\
\text { of } \mathrm{Tx}\end{array}$} & \multirow{2}{*}{ Prior $A L K \mathrm{i}$} & \multirow{2}{*}{$\begin{array}{l}\text { No. of patients } \\
\text { with } B M\end{array}$} & \multicolumn{2}{|l|}{ IC-ORR } & \multicolumn{2}{|l|}{ IC-DCR } & \multicolumn{2}{|l|}{ IC-DOR } \\
\hline & & & & & & & $\begin{array}{l}\text { measurable } \\
\text { BM: } \%, n\end{array}$ & $\begin{array}{l}\text { all patients } \\
\text { with BM at } \\
\text { baseline }\end{array}$ & $\begin{array}{l}\text { measurable/ } \\
\text { target BM: } \\
\%, n\end{array}$ & $\begin{array}{l}\text { all patients with } \\
\text { BM at baseline }\end{array}$ & $\begin{array}{l}\text { measurable/ } \\
\text { target BM: } \\
\%, n\end{array}$ & $\begin{array}{l}\text { all patients with } \\
\text { BM at baseline }\end{array}$ \\
\hline \multirow[t]{2}{*}{$\begin{array}{l}\text { 1st } \\
\text { generation }\end{array}$} & Crizotinib & $\begin{array}{l}\text { ALK, MET, } \\
\text { ROS1 }\end{array}$ & $\begin{array}{l}\text { PROFILE1005 } \\
\text { and PROFILE1007 }\end{array}$ & $\geq 2$ nd & $A L K \mathrm{i}$-naĩve & $\begin{array}{l}\text { Crizotinib+RT: } \\
166\end{array}$ & $33(6 / 18)$ & l & l & $12 \mathrm{w}, 62(103 / 166)$ & l & NR (166) \\
\hline & & & & & & Crizotinib: 109 & $18(4 / 22)$ & I & I & 12w: $56(61 / 109)$ & 1 & 26.4 ws (109) \\
\hline \multirow[t]{13}{*}{$\begin{array}{l}\text { 2nd } \\
\text { generation }\end{array}$} & Alectinib & $\begin{array}{l}A L K, R E T \text {; low } \\
\text { anti-ROS1 }\end{array}$ & AF-002JG & $\geq 2$ nd & $\begin{array}{l}\text { Crizotinib- } \\
\text { pretreated }\end{array}$ & 21 & $56(5 / 9)$ & $52(11 / 21)$ & $78(7 / 9)$ & $90(19 / 21)$ & l & I \\
\hline & Alectinib & & $\begin{array}{l}\text { NP28761 and } \\
\text { NP28673 }\end{array}$ & $\geq 2$ nd & $\begin{array}{l}\text { Crizotinib- } \\
\text { pretreated }\end{array}$ & 136 & $64(32 / 50)$ & $43(58 / 136)$ & $90(45 / 50)$ & $85(116 / 136)$ & 10.8 months $(50)$ & 11.1 months (136) \\
\hline & Alectinib & & ALUR & $\geq 2$ nd & $\begin{array}{l}\text { Crizotinib- } \\
\text { pretreated }\end{array}$ & 50 & $54(13 / 24)$ & $36(18 / 50)$ & $79(19 / 24)$ & $80(40 / 50)$ & $\begin{array}{l}\text { NR ( } 3.6 \text { months- } \\
\text { NR) (24) }\end{array}$ & I \\
\hline & Alectinib & & ALEX & 1st & $A L K$ i-naïve & 64 & $81(17 / 21)$ & $59(38 / 64)$ & I & 1 & 17.3 months $(21)$ & NR (64) \\
\hline & Ceritinib & $\begin{array}{l}A L K, \text { ROS1, } \\
\text { IGF1 }\end{array}$ & ASCEND-1 & $\geq 1$ st & $\begin{array}{l}\text { ALKi-naïve } \\
(19 / 94)\end{array}$ & 19 & $63(5 / 8)$ & $42(8 / 19)$ & $63(5 / 8)$ & $79(15 / 19)$ & 8.2 months (8) & NR (19) \\
\hline & & & & & $\begin{array}{l}\text { ALKi-pretreated } \\
(75 / 94)\end{array}$ & 75 & $36(10 / 28)$ & $19(14 / 75)$ & $61(17 / 28)$ & $65(49 / 75)$ & 11.1 months (28) & 6.9 months $(75)$ \\
\hline & Ceritinib & $\begin{array}{l}\text { ALK, ROS1, } \\
\text { IGF1 }\end{array}$ & ASCEND-2 & $\geq 2$ nd & $\begin{array}{l}\text { Crizotinib- } \\
\text { pretreated }\end{array}$ & 100 & $45(9 / 20)^{*}$ & $33(33 / 100)$ & $80(16 / 20)^{*}$ & $74(74 / 100)$ & I & 9.2 months (100) \\
\hline & Ceritinib & $\begin{array}{l}A L K, R O S 1, \\
\text { IGF1 }\end{array}$ & ASCEND-4 & 1 st & $A L K \mathrm{i}$-naïve & 54 & $73(16 / 22)$ & $46(54)$ & $86(22)$ & $89(54)$ & I & I \\
\hline & Ceritinib & $\begin{array}{l}A L K, R O S 1, \\
\text { IGF1 }\end{array}$ & ASCEND-5 & $\geq 2$ nd & $\begin{array}{l}\text { Crizotinib- } \\
\text { pretreated }\end{array}$ & 17 & $35(6 / 17)^{*}$ & & & & & 6.9 months (17) \\
\hline & Brigatinib & $A L K, R O S 1$ & ALTA & $\geq 2$ nd & $\begin{array}{l}\text { Crizotinib- } \\
\text { pretreated }\end{array}$ & armA: $90 \mathrm{mg}$ qd & $42(11 / 26)$ & I & $85(22 / 26)$ & 1 & $\begin{array}{l}\text { NR ( } 3.7 \text { months- } \\
\text { NR) (26) }\end{array}$ & I \\
\hline & & & & & & & $42(8 / 19)^{\#}$ & l & $84(16 / 19)^{\#}$ & 1 & 1 & I \\
\hline & & & & & & armB: $180 \mathrm{mg}$ qd & $67(12 / 18)$ & I & $83(15 / 18)$ & l & $\begin{array}{l}\text { NR ( } 5.6 \text { months- } \\
\text { NR) (18) }\end{array}$ & I \\
\hline & & & & & & & $73(11 / 15)^{\#}$ & l & $93(14 / 15)^{\#}$ & l & 1 & I \\
\hline $\begin{array}{l}\text { 3rd } \\
\text { generation }\end{array}$ & Lorlatinib & $A L K, R O S 1$ & ASCO report & $\geq 2$ nd & $\begin{array}{l}\text { ALKi- } \\
\text { pretreated }\end{array}$ & 18 & $39(7)$ & I & I & I & I & I \\
\hline
\end{tabular}

BM, brain metastasis; Tx, treatments; IC, intracranial; ORR, overall response rate; $\mathrm{CR}+\mathrm{PR}$, DCR, disease control rate; $\mathrm{CR}+\mathrm{PR}+\mathrm{SD}$, DOR, duration of response; NR, not reached. Measurable, brain lesions with longest diameter $\geq 10 \mathrm{~mm}$. * Target BM, target lesion indicated that the lesion was active (a new or existing lesion that progressed after local therapy). * Active brain metastasis, defined as lesions without prior radiotherapy or those with investigator-assessed progression after prior radiotherapy.

treatment for advanced $A L K$-positive NSCLC patients, followed by ceritinib and brigatinib. However, the NCCN Panel voted that alectinib is the preferred agent for ALKi-naïve NSCLC patients. Further clinical trials are required on whether other next-generation $A L K$ TKI would be the first-line treatment options for advanced NSCLC with $A L K$ rearrangement. We look forward to the results.

The efficacy of the combination of radiotherapy and the next-generation $A L K$-TKI has not been widely studied. ASCEND-1 [14] was a multi-center research exploring the efficacy and safety of ceritinib, enrolling $19 \mathrm{ALKi}$ naïve patients of which 11 received radiotherapy combined with ceritinib and 8 cases received ceritinib alone. The results showed that DCR $(\mathrm{CR}+\mathrm{PR}+\mathrm{SD}, 72.7$ vs. $87.5 \%)$ and ORR (36.4 vs. $50 \%$ ) present no significant difference between the two groups. Furthermore, ASCEND-4 reached a similar conclusion [16]. It perhaps indicates that ceritinib has strong local control capacities and good treatment responses on BM lesions, and the effect is not dependent on the administration of combined radiotherapy. However, due to the small sample numbers and the retrospective nature of the study, conclusions might be controversial, and further researches are needed.

\section{Treatment on Crizotinib-Refractory Patients}

\section{Radiotherapy in Crizotinib-Refractory Patients}

During treatment of crizotinib, new-onset BM or the progression of previous BM lesions still occurred even if extracranial lesions were well controlled, that is, CNS resistance/refraction of crizotinib, which might be related to the low blood-brain barrier permeability of crizotinib. At an oral dose of $200 \mathrm{mg} /$ b.i.d., the cerebrospinal fluid/ plasma ratio of crizotinib was only 0.002631 [36]. However, studies had shown that although the concentration of crizotinib in cerebrospinal fluid was low, it still had anti-tumor efficacy on IC lesions [32]. Therefore, the low drug concentration in cerebrospinal fluid could not fully explain the IC resistance of crizotinib, and its acquired gene changes (such as $A L K$ tyrosine kinase mutation, $A L K$ copy number variation, activation of other oncogenic pathways, etc.) might participate in the progression of $\mathrm{BM}$ after $A L K$-TKI resistance. In recent years, mutation of gatekeeper genes (such as G1202R mutation) had been widely recognized by researchers, since it shared similarities with the EGFR T790M mutation. However, the G1202R mutation was more difficult to treat. Anyway, according to previous data, only $20 \%$ of the $A L K$-positive NSCLC patients would present with drug-resistant muta- 
tions [37], with various categories and wide ranges. Therefore, the mechanism of resistance to crizotinib was still unclear.

Administration of brain radiotherapy could achieve better local control rate for new-onset $\mathrm{BM}$ or progression of previous BM during crizotinib treatment. In the PROFILE1005 and 1007 trials [8], 34 patients with asymptomatic progressive brain lesions during crizotinib application were enrolled, and 27 patients received brain radiotherapy. The median treatment duration after progressive disease (PD) of these 27 patients was 19.3 weeks. In other small sample reports, the median PFS of patients with crizotinib-refractory CNS lesions, after administration of brain radiotherapy, reached 5.5-7.1 months [8, $27,38]$. In these studies, crizotinib beyond disease progression was continued simultaneously with brain radiotherapy after brain lesion progression. Ou et al. [39] analyzed 194 crizotinib-treated patients with RECISTdefined PD and found that CBPD patients had significantly a longer OS from the time of PD (median 16.4 vs. 3.9 months, $p<0.0001$ ) and from the time of initial crizotinib treatment (median 29.6 vs. 10.8 months, $p<0.0001)$. Thus, for patients who progressed after crizotinib, crizotinib beyond disease progression combined with radiotherapy could help control IC lesions and prolong OS $[8,39,40]$. However, these conclusions were drawn from retrospective and not controlled researches, some of which had a small sample size, and the level of evidence was not high. Further prospective trials of large sample size are recommended to get more convincing conclusions.

\section{Next-Generation ALK-TKI in Crizotinib-Refractory Patients}

A number of studies showed $[13,14,41,42]$ that second-/third-generation $A L K$-TKI had a strong anti-tumor activity in crizotinib-refractory patients, and its ORR reached $35.7-81 \%$ while the median PFS was 5.412.9 months. Furthermore, by horizontal comparison of different studies, their effect on BM seemed to be superior to crizotinib even in crizotinib-refractory patients (Table 1). ASCEND series evaluated efficacy of ceritinib, of which IC ORR reached $45 \%$ for crizotinib-refractory BM patients in the ASCEND-2 study [13], and 35\% in ASCEND-5 [15]. The ongoing ASCEND-7 trial aimed to identify the anti-CNS metastasis activity of ceritinib. Alectinib also showed great efficacy in controlling BM $[17,18,43,44]$, and played a role in meningeal metastasis $[43,44]$. By analyzing 50 crizotinib-refractory patients with measurable brain lesions in the NP28763 and NP28761 studies [18], IC-ORR of alectinib reached 64\% (of which $22 \%$ reached CR). The ALUR trial $[19,45]$ was the only research comparing the efficacy of alectinib with standard chemotherapy in crizotinib-refractory patients, and the results showed that PFS (9.6 vs. 1.4 months, $p<0.001)$ and the CNS response rate (54.2 vs. $0 \%, p<0.001)$ in the alectinib group were significantly improved. The ALTA study [21] showed that for crizotinib-refractory NSCLC patients, the ORR of brigatinib for IC measurable lesions was as high as $67 \%(n=18)$. As a third-generation $A L K$ inhibitor, lorlatinib showed high CNS permeability. In a study of 18 crizotinib-refractory patients, the IC-ORR was $39 \%$, and it was very effective for the G1202R mutation [46]. At present, second-generation $A L K$ inhibitors, including ceritinib, alectinib, and brigatinib, have been approved by FDA for the treatment of metastatic crizotinib-refractory NSCLC patients.

There were few trials focusing on radiotherapy combining with next-generation $A L K$ inhibitors in the treatment of crizotinib-refractory NSCLC patients. In the ASCEND-1 study [14], there were no significant differences in IC-DCR (65.4 vs. 65.2\%) and IC-ORR (17.3 vs. $21.7 \%)$ in $75 \mathrm{ALKi}$-pretreated patients with or without radiotherapy, suggesting that radiotherapy might have little curative effect when ceritinib was used. In a pooled analysis (NP28761 and NP28673 studies) [18] on CNS response to alectinib in $A L K$ i-pretreated patients, a similar conclusion was drawn. In this study, 95 patients received radiotherapy, and 41 patients had no previous radiotherapy. The IC-DCR were 86.3 and $82.9 \%$, while the ICORR were 35.8 and $58.5 \%$, respectively. It is generally believed that radiation therapy could destroy the bloodbrain barrier and improve the permeability of target drugs so as to improve the control rate of CNS. However, the efficacy of next-generation $A L K$ inhibitors on IC tumors seems not to be affected by previous radiotherapy application, and this may be explained by its powerful anti-CNS metastasis activity. Anyway, further conclusions should be drawn from large prospective randomized controlled trails.

Alectinib, as a second-generation $A L K$ inhibitor, might show a pseudoprogression (PsP) phenomenon during the treatment of $\mathrm{BM}$ that had previously been treated by radiotherapy. Ou et al. [47] reported two cases with PsPs who had been treated by alectinib 4 months later after SRS. Images showed enlarged lesions within the previous radiation field that was enhanced after contrast, which was difficult to distinguish from a real disease progression. Postoperative pathology showed necrosis and no tumor remains. Anyway, till now, no radiation necrosis, or PsP, has been reported after the application of crizotinib, which indirectly reflects the stronger efficacy of alectinib on CNS metastasis. Therefore, in the treatment of alectinib, when suspicious progression appears within the radiation field while no progression shows outside, close monitoring and more sensitive images to identify PsP are needed. 


\section{Choice of Radiotherapy: SRS versus WBRT}

There are few studies on the radiosensitivity of $A L K$ rearrangement NSCLC with brain metastases. Researches based on EML4- $A L K$ rearrangement cell lines and clinical statistics shows that $A L K$-positive NSCLC is a radiosensitive tumor [48, 49]. Johung et al. [50] prospectively analyzed $79 \mathrm{BM}$ patients (469 cranial lesions) treated with Gamma knife and found no recurrence within the radiation field in patients with EGFR mutation or $A L K$ rearrangements (patients, 0/30; lesions, 0/225), which was significantly lower than those without the above changes (patients, 9/49; lesions, 13/244), while no significant recurrence rate difference existed outside the radiation field ( 53 vs. $47 \%, p=0.58$ ). For patients with these molecular changes, the recurrence-free survival time within the radiation field was significant longer than for those without such changes (not reached vs. 18.4 months), while there was no difference outside the radiation field in the brain. Multivariate analysis showed that EGFR or EML4-ALK change and small lesion size were good prognostic factors after gamma knife treatment. These above researches laid the foundation for radiation application in $A L K$ rearrangement patients with brain metastases.

SRS and WBRT are both local treatment options for brain metastases. A number of randomized trials showed that WBRT combined with SRS did not bring survival benefits for patients with 1-4brain lesions [51-54], while healthrelated quality of life and neurocognitive function might decrease after WBRT [55, 56]. Recently, many studies [57-60] found that SRS was comparable to WBRT in controlling 4 or more brain lesions. Based on these studies, some researchers suggested SRS as the first choice in ALK-positive NSCLC patients with brain metastases, namely delayed WBRT, and for patients with diffuse brain metastases or meningeal metastases, WBRT should be first considered [61].

However, SRS had some limitations. Some studies shown that recurrence within the radiation field after SRS increased with the enlargement of the tumor volume and occurrence of necrotic lesions $[62,63]$ while IC freedom from progression decreased with the increase in lesion numbers [64]. In addition, some scholars also questioned neurocognitive function reduction after WBRT. Previous studies $[56,65]$ reported that brain cognitive impairment occurred 3-4 months after radiotherapy, while some studies $[66,67]$ suggested that the reduction was temporary and could be improved later. In recent years, studies $[68,69]$ have shown that WBRT with hippocampus protection could reduce the damage of neurocognitive function without decreasing the local control rate. Moreover, $A L K$ rearrangement more often occurred in young and nonsmoking female patients who might suffer less from cognitive function impairment than non- $A L K$ rearrangement NSCLC patients with brain metastases $[22,70]$.
There are few studies on SRS/WBRT selection for $A L K$-positive NSCLC patients with BM. Johung et al. [4] analyzed 90 cases (53\% of the patients with 3 or less brain lesions) treated with radiotherapy and $A L K$ inhibitors and found that there was no significant difference between SRS and WBRT regarding OS, but SRS tended to be inferior to WBRT with regard to PFS $(p=0.082)$. In conclusion, the selection of SRS and WBRT in ALK rearrangement NSCLC patients with BM is still controversial, and the choice is hard to make. More prospective clinical trials are needed.

\section{Conclusion}

In conclusion, for $A L K$ i-naïve $A L K$ rearrangement NSCLC patients, crizotinib had a poor therapeutic effect on IC lesions, while combining with radiotherapy might improve the IC control rate, PFS, and very likely improve OS; other next-generation $A L K$-TKIs are now replacing crizotinib as the first-line treatment for $A L K$-positive NSCLC with BM. For patients with CNS progression during crizotinib application, combining radiotherapy might improve the local control rate while continuing crizotinib to control systemic disease. In addition, second-/thirdgeneration $A L K$ inhibitors have higher IC ORR and DCR even after crizotinib-refractory situations, which could be used as one of the therapeutic options, and currently, some studies show that next-generation $A L K$-TKI alone has a strong efficacy against IC tumors, in which situation radiotherapy could be omitted. Anyway, studies focusing on options of BM treatment are few, and we draw conclusions from some retrospective trials. We look forward to prospective randomized controlled clinical trials to offer a confirmed choice of drugs and radiation.

Although next-generation ALK inhibitors have shown strong anti-CNS metastasis effects, drug resistance will eventually occur, and unlike EGFR resistance, of which the T790M mutation accounted for more than $50 \%, A L K$ resistance is more complicated, with a wide range of molecular changes. Further studies are needed to solve the above problems. In addition, as an effective local treatment, whether radiation therapy should be combined with the next-generation $A L K$-TKI is still an open question. The treatment of $A L K$ rearrangement NSCLC with $\mathrm{BM}$ requires multidisciplinary participation. How to optimize the whole process through a variety of treatment options needs to be solved by further clinical practice.

\section{Disclosure Statement}

The authors declare that they have no competing interests. 


\section{References}

1 Metro G, Tazza M, Matocci R, Chiari R, Crinò L. Optimal management of ALK-positive NSCLC progressing on crizotinib. Lung Cancer. 2017 Apr;106:58-66.

2 Sperduto PW, Yang TJ, Beal K, Pan H, Brown PD, Bangdiwala A, et al. Estimating Survival in Patients With Lung Cancer and Brain Metastases: An Update of the Graded Prognostic Assessment for Lung Cancer Using Molecular Markers (Lung-molGPA). JAMA Oncol. 2017 Jun;3(6):827-31.

3 Rangachari D, Yamaguchi N, VanderLaan PA, Folch E, Mahadevan A, Floyd SR, et al. Brain metastases in patients with EGFR-mutated or ALK-rearranged non-small-cell lung cancers. Lung Cancer. 2015 Apr;88(1):10811.

4 Johung KL, Yeh N, Desai NB, Williams TM, Lautenschlaeger T, Arvold ND, et al. Extended Survival and Prognostic Factors for Patients With ALK-Rearranged Non-Small-Cell Lung Cancer and Brain Metastasis. J Clin Oncol. 2016 Jan;34(2):123-9.

5 Guérin A, Sasane M, Zhang J, Culver KW, Dea K, Nitulescu R, et al. Brain metastases in patients with ALK+ non-small cell lung cancer: clinical symptoms, treatment patterns and economic burden. J Med Econ. 2015 Apr; 18(4):312-22

6 Jena A, Taneja S, Talwar V, Sharma JB. Magnetic resonance (MR) patterns of brain metastasis in lung cancer patients: correlation of imaging findings with symptom. J Thorac Oncol. 2008 Feb;3(2):140-4.

7 Komatsu T, Kunieda E, Oizumi Y, Tamai Y, Akiba T. Clinical characteristics of brain metastases from lung cancer according to histological type: pretreatment evaluation and survival following whole-brain radiotherapy. Mol Clin Oncol. 2013 Jul;1(4):692-8.

8 Costa DB, Shaw AT, Ou SH, Solomon BJ, Riely GJ, Ahn MJ, et al. Clinical Experience With Crizotinib in Patients With Advanced ALK-Rearranged Non-Small-Cell Lung Cancer and Brain Metastases. J Clin Oncol. 2015 Jun;33(17):1881-8.

9 Sperduto PW, Chao ST, Sneed PK, Luo X, Suh J, Roberge D, et al. Diagnosis-specific prognostic factors, indexes, and treatment outcomes for patients with newly diagnosed brain metastases: a multi-institutional analysis of 4,259 patients. Int J Radiat Oncol Biol Phys. 2010 Jul;77(3):655-61.

10 Sperduto PW, Kased N, Roberge D, Xu Z, Shanley R, Luo X, et al. Summary report on the graded prognostic assessment: an accurate and facile diagnosis-specific tool to estimate survival for patients with brain metastases. J Clin Oncol. 2012 Feb;30(4):419-25.

11 Masters GA, Temin S, Azzoli CG, Giaccone G, Baker S Jr, Brahmer JR, et al.; American Society of Clinical Oncology Clinical Practice. Systemic Therapy for Stage IV Non-SmallCell Lung Cancer: American Society of Clinical Oncology Clinical Practice Guideline Update. J Clin Oncol. 2015 Oct;33(30):3488515.

12 Novello S, Barlesi F, Califano R, Cufer T, Ekman S, Levra MG, et al.; ESMO Guidelines Committee. Metastatic non-small-cell lung cancer: ESMO Clinical Practice Guidelines for diagnosis, treatment and follow-up. Ann Oncol. 2016 Sep;27 suppl 5:v1-27.

13 Crinò L, Ahn MJ, De Marinis F, Groen HJ, Wakelee H, Hida T, et al. Multicenter Phase II Study of Whole-Body and Intracranial Activity With Ceritinib in Patients With ALKRearranged Non-Small-Cell Lung Cancer Previously Treated With Chemotherapy and Crizotinib: results From ASCEND-2. J Clin Oncol. 2016 Aug;34(24):2866-73.

14 Kim DW, Mehra R, Tan DS, Felip E, Chow LQ, Camidge DR, et al. Activity and safety of ceritinib in patients with ALK-rearranged non-small-cell lung cancer (ASCEND-1): updated results from the multicentre, open-label, phase 1 trial. Lancet Oncol. 2016 Apr; 17(4):452-63.

15 Shaw AT, Kim TM, Crinò L, Gridelli C, Kiura $\mathrm{K}$, Liu G, et al. Ceritinib versus chemotherapy in patients with ALK-rearranged non-smallcell lung cancer previously given chemotherapy and crizotinib (ASCEND-5): a randomised, controlled, open-label, phase 3 trial. Lancet Oncol. 2017 Jul;18(7):874-86.

16 Soria JC, Tan DS, Chiari R, Wu YL, Paz-Ares $\mathrm{L}$, Wolf J, et al. First-line ceritinib versus platinum-based chemotherapy in advanced ALKrearranged non-small-cell lung cancer (ASCEND-4): a randomised, open-label, phase 3 study. Lancet. 2017 Mar;389(10072):917-29.

17 Gadgeel SM, Gandhi L, Riely GJ, Chiappori AA, West HL, Azada MC, et al. Safety and activity of alectinib against systemic disease and brain metastases in patients with crizotinib-resistant ALK-rearranged non-small-cell lung cancer (AF-002JG): results from the dose-finding portion of a phase 1/2 study. Lancet Oncol. 2014 Sep;15(10):1119-28.

18 Gadgeel SM, Shaw AT, Govindan R, Gandhi L, Socinski MA, Camidge DR, et al. Pooled Analysis of CNS Response to Alectinib in Two Studies of Pretreated Patients With ALK-Positive Non-Small-Cell Lung Cancer. J Clin Oncol. 2016 Dec;34(34):4079-85.

19 Novello S, Mazières J, Oh IJ, de Castro J, Migliorino MR, Helland $\AA$, et al. Alectinib versus chemotherapy in crizotinib-pretreated anaplastic lymphoma kinase (ALK)-positive non-small-cell lung cancer: results from the phase III ALUR study. Ann Oncol. 2018 Jun; 29(6):1409-16.

20 Peters S, Camidge DR, Shaw AT, Gadgeel S, Ahn JS, Kim DW, et al.; ALEX Trial Investigators. Alectinib versus Crizotinib in Untreated ALK-Positive Non-Small-Cell Lung Cancer. N Engl J Med. 2017 Aug;377(9):829-38.

21 Kim DW, Tiseo M, Ahn MJ, Reckamp KL, Hansen KH, Kim SW, et al. Brigatinib in Patients With Crizotinib-Refractory Anaplastic Lymphoma Kinase-Positive Non-Small-Cell Lung Cancer: A Randomized, Multicenter Phase II Trial. J Clin Oncol. 2017 Aug;35(22):2490-8.

22 Kwak EL, Bang YJ, Camidge DR, Shaw AT, Solomon B, Maki RG, et al. Anaplastic lymphoma kinase inhibition in non-small-cell lung cancer. N Engl J Med. 2010 Oct;363(18): 1693-703.

23 Soda M, Takada S, Takeuchi K, Choi YL, Enomoto $\mathrm{M}$, Ueno $\mathrm{T}$, et al. A mouse model for
EML4-ALK-positive lung cancer. Proc Natl Acad Sci USA. 2008 Dec;105(50):19893-7.

24 Koivunen JP, Mermel C, Zejnullahu K, Murphy C, Lifshits E, Holmes AJ, et al. EML4ALK fusion gene and efficacy of an ALK kinase inhibitor in lung cancer. Clin Cancer Res. 2008 Jul;14(13):4275-83.

25 Camidge DR, Bang YJ, Kwak EL, Iafrate AJ, Varella-Garcia M, Fox SB, et al. Activity and safety of crizotinib in patients with ALK-positive non-small-cell lung cancer: updated results from a phase 1 study. Lancet Oncol. 2012 Oct;13(10):1011-9.

26 Solomon BJ, Mok T, Kim DW, Wu YL, Nakagawa K, Mekhail T, et al.; PROFILE 1014 Investigators. First-line crizotinib versus chemotherapy in ALK-positive lung cancer. N Engl J Med. 2014 Dec;371(23):2167-77.

27 Weickhardt AJ, Scheier B, Burke JM, Gan G, Lu X, Bunn PA Jr, et al. Local ablative therapy of oligoprogressive disease prolongs disease control by tyrosine kinase inhibitors in oncogene-addicted non-small-cell lung cancer. J Thorac Oncol. 2012 Dec;7(12):1807-14.

28 Yoshida T, Oya Y, Tanaka K, Shimizu J, Horio $\mathrm{Y}$, Kuroda H, et al. Clinical impact of crizotinib on central nervous system progression in ALK-positive non-small lung cancer. Lung Cancer. 2016 Jul;97:43-7.

29 Lv J, Zhang Q, Qin N, Yang X, Zhang X, Wu $\mathrm{Y}$, et al. [Treatment of Patients with ALK-positive Non-small Cell Lung Cancer and Brain Metastases]. Zhongguo Fei Ai Za Zhi. 2016 Aug;19(8):519-24.

30 Bianco C, Tortora G, Bianco R, Caputo R, Veneziani BM, Caputo R, et al. Enhancement of antitumor activity of ionizing radiation by combined treatment with the selective epidermal growth factor receptor-tyrosine kinase inhibitor ZD1839 (Iressa). Clin Cancer Res. 2002 Oct; $8(10): 3250-8$

31 Shukuya T, Takahashi T, Naito T, Kaira R, Ono A, Nakamura Y, et al. Continuous EGFR-TKI administration following radiotherapy for non-small cell lung cancer patients with isolated CNS failure. Lung Cancer. 2011 Dec;74(3):457-61.

32 Metro G, Lunardi G, Floridi P, Pascali JP, Marcomigni L, Chiari R, et al. CSF Concentration of Crizotinib in Two ALK-Positive Non-SmallCell Lung Cancer Patients with CNS Metastases Deriving Clinical Benefit from Treatment. J Thorac Oncol. 2015 May;10(5):e26-7.

33 Yuan H, Gaber MW, Boyd K, Wilson CM, Kiani MF, Merchant TE. Effects of fractionated radiation on the brain vasculature in a murine model: blood-brain barrier permeability, astrocyte proliferation, and ultrastructural changes. Int J Radiat Oncol Biol Phys. 2006 Nov;66(3):860-6.

34 Kinoshita Y, Koga Y, Sakamoto A, Hidaka K: Long-lasting response to crizotinib in brain metastases due to EML4-ALK-rearranged non-small-cell lung cancer. BMJ Case Rep. 2013 Sep;2013:200867.

35 Kaneda H, Okamoto I, Nakagawa K. Rapid response of brain metastasis to crizotinib in a patient with ALK rearrangement-positive non-small-cell lung cancer. J Thorac Oncol. 2013 Apr;8(4):e32-3. 
36 Costa DB, Kobayashi S, Pandya SS, Yeo WL, Shen Z, Tan W, et al. CSF concentration of the anaplastic lymphoma kinase inhibitor crizotinib. J Clin Oncol. 2011 May;29(15):e443-5.

37 Gainor JF, Dardaei L, Yoda S, Friboulet L, Leshchiner I, Katayama R, et al. Molecular Mechanisms of Resistance to First- and Second-Generation ALK Inhibitors in ALK-Rearranged Lung Cancer. Cancer Discov. 2016 Oct;6(10):1118-33.

38 Takeda M, Okamoto I, Nakagawa K. Clinical impact of continued crizotinib administration after isolated central nervous system progression in patients with lung cancer positive for ALK rearrangement. J Thorac Oncol. 2013 May;8(5):654-7.

39 Ou SH, Jänne PA, Bartlett CH, Tang Y, Kim DW, Otterson GA, et al. Clinical benefit of continuing ALK inhibition with crizotinib beyond initial disease progression in patients with advanced ALK-positive NSCLC. Ann Oncol. 2014 Feb;25(2):415-22.

40 Camidge DR, Doebele RC. Treating ALKpositive lung cancer-early successes and future challenges. Nat Rev Clin Oncol. 2012 Apr;9(5):268-77.

$41 \mathrm{Ou} \mathrm{SH}$, Ahn JS, De Petris L, Govindan R, Yang JC, Hughes B, et al. Alectinib in Crizotinib-Refractory ALK-Rearranged Non-Small-Cell Lung Cancer: A Phase II Global Study. J Clin Oncol. 2016 Mar;34(7): 661-8.

42 Shaw AT, Gandhi L, Gadgeel S, Riely GJ, Cetnar J, West $\mathrm{H}$, et al.; study investigators. Alectinib in ALK-positive, crizotinib-resistant, non-small-cell lung cancer: a singlegroup, multicentre, phase 2 trial. Lancet Oncol. 2016 Feb;17(2):234-42.

43 Metro G, Lunardi G, Bennati C, Chiarini P, Sperduti I, Ricciuti B, et al. Alectinib's activity against CNS metastases from ALK-positive non-small cell lung cancer: a single institution case series. J Neurooncol. 2016 Sep;129(2): 355-61.

$44 \mathrm{Ou}$ SH, Sommers KR, Azada MC, Garon EB. Alectinib induces a durable ([\{GT\}]15 months) complete response in an ALK-positive non-small cell lung cancer patient who progressed on crizotinib with diffuse leptomeningeal carcinomatosis. Oncologist. 2015 Feb;20(2):224-6.

45 Novello S, Mazieres J, Oh IJ, de Castro J, Migliorino MR, Helland A, et al. Primary results from the phase III ALUR study of alectinib versus chemotherapy in previously treated ALK+ non-small-cell lung cancer (NSCLC). Ann Oncol. 2017;28(suppl 5):v605-v649.

46 Lorlatinib Is Active in Drug-Resistant NSCLC. Cancer Discov. 2016 Aug;6(8):OF1.

47 Ou SH, Klempner SJ, Azada MC, RauseiMills V, Duma C. Radiation necrosis presenting as pseudoprogression (PsP) during alectinib treatment of previously radiated brain metastases in ALK-positive NSCLC: implications for disease assessment and management. Lung Cancer. 2015 Jun;88(3): 355-9.

48 Dai Y, Wei Q, Schwager C, Hanne J, Zhou C, Herfarth $\mathrm{K}$, et al. Oncogene addiction and ra- diation oncology: effect of radiotherapy with photons and carbon ions in ALK-EML4 translocated NSCLC. Radiat Oncol. 2018 Jan; 13(1): 1 .

49 Dai Y, Wei Q, Schwager C, Moustafa M, Zhou $\mathrm{C}$, Lipson KE, et al. Synergistic effects of crizotinib and radiotherapy in experimental EML4-ALK fusion positive lung cancer. Radiother Oncol. 2015 Feb;114(2):173-81.

50 Johung KL, Yao X, Li F, Yu JB, Gettinger SN, Goldberg S, et al. A clinical model for identifying radiosensitive tumor genotypes in nonsmall cell lung cancer. Clin Cancer Res. 2013 Oct;19(19):5523-32.

51 Aoyama H, Tago M, Shirato H; Japanese Radiation Oncology Study Group 99-1 (JROSG 99-1) Investigators. Stereotactic Radiosurgery With or Without Whole-Brain Radiotherapy for Brain Metastases: Secondary Analysis of the JROSG 99-1 Randomized Clinical Trial. JAMA Oncol. 2015 Jul;1(4):457-64.

52 Shaw E, Scott C, Souhami L, Dinapoli R, Kline $\mathrm{R}$, Loeffler J, et al. Single dose radiosurgical treatment of recurrent previously irradiated primary brain tumors and brain metastases: final report of RTOG protocol 90-05. Int J Radiat Oncol Biol Phys. 2000 May;47(2):291-8.

53 Aoyama H, Shirato H, Tago M, Nakagawa K, Toyoda T, Hatano K, et al. Stereotactic radiosurgery plus whole-brain radiation therapy vs stereotactic radiosurgery alone for treatment of brain metastases: a randomized controlled trial. JAMA. 2006 Jun;295(21):2483-91.

54 Kocher M, Soffietti R, Abacioglu U, Villà S, Fauchon F, Baumert BG, et al. Adjuvant whole-brain radiotherapy versus observation after radiosurgery or surgical resection of one to three cerebral metastases: results of the EORTC 22952-26001 study. J Clin Oncol. 2011 Jan;29(2):134-41.

55 Soffietti R, Kocher M, Abacioglu UM, Villa S, Fauchon F, Baumert BG, et al. A European Organisation for Research and Treatment of Cancer phase III trial of adjuvant whole-brain radiotherapy versus observation in patients with one to three brain metastases from solid tumors after surgical resection or radiosurgery: quality-of-life results. J Clin Oncol. 2013 Jan;31(1):65-72.

56 Chang EL, Wefel JS, Hess KR, Allen PK, Lang FF, Kornguth DG, et al. Neurocognition in patients with brain metastases treated with radiosurgery or radiosurgery plus whole-brain irradiation: a randomised controlled trial. Lancet Oncol. 2009 Nov;10(11):1037-44.

57 Bhatnagar AK, Flickinger JC, Kondziolka D, Lunsford LD. Stereotactic radiosurgery for four or more intracranial metastases. Int J Radiat Oncol Biol Phys. 2006 Mar;64(3):898903

58 Chang WS, Kim HY, Chang JW, Park YG, Chang JH. Analysis of radiosurgical results in patients with brain metastases according to the number of brain lesions: is stereotactic radiosurgery effective for multiple brain metastases? J Neurosurg. 2010 Dec;113(Special_ Supplement Suppl):73-8.

59 Likhacheva A, Pinnix CC, Parikh NR, Allen PK, McAleer MF, Chiu MS, et al. Predictors of survival in contemporary practice after initial radiosurgery for brain metastases. Int J Radiat Oncol Biol Phys. 2013 Mar;85(3):65661.

60 Yamamoto M, Serizawa T, Shuto T, Akabane A, Higuchi Y, Kawagishi J, et al. Stereotactic radiosurgery for patients with multiple brain metastases (JLGK0901): a multi-institutional prospective observational study. Lancet Oncol. 2014 Apr;15(4):387-95.

61 Rusthoven CG, Doebele RC. Management of Brain Metastases in ALK-Positive NonSmall-Cell Lung Cancer. J Clin Oncol. 2016 Aug;34(24):2814-9.

62 Vogelbaum MA, Angelov L, Lee SY, Li L, Barnett GH, Suh JH. Local control of brain metastases by stereotactic radiosurgery in relation to dose to the tumor margin. J Neurosurg. 2006 Jun;104(6):907-12.

63 Goodman KA, Sneed PK, McDermott MW, Shiau CY, Lamborn KR, Chang S, et al. Relationship between pattern of enhancement and local control of brain metastases after radiosurgery. Int J Radiat Oncol Biol Phys. 2001 May;50(1):139-46.

64 Chitapanarux I, Goss B, Vongtama R, Frighetto L, De Salles A, Selch M, et al. Prospective study of stereotactic radiosurgery without whole brain radiotherapy in patients with four or less brain metastases: incidence of intracranial progression and salvage radiotherapy. J Neurooncol. 2003 Jan;61(2):143-9.

65 Brown PD, Asher AL, Ballman KV, Farace E, Cerhan JH, Anderson SK, et al. NCCTG N0574 (Alliance): A phase III randomized trial of whole brain radiation therapy (WBRT) in addition to radiosurgery (SRS) in patients with 1 to 3 brain metastases. J Clin Oncol. 2015. Available from: https://ascopubs.org/ doi/abs/10.1200/jco.2015.33.18_suppl.lba4.

66 Armstrong CL, Corn BW, Ruffer JE, Pruitt AA, Mollman JE, Phillips PC. Radiotherapeutic effects on brain function: double dissociation of memory systems. Neuropsychiatry Neuropsychol Behav Neurol. 2000 Apr;13(2): 101-11.

67 McDuff SG, Taich ZJ, Lawson JD, Sanghvi P, Wong ET, Barker FG 2nd, et al. Neurocognitive assessment following whole brain radiation therapy and radiosurgery for patients with cerebral metastases. J Neurol Neurosurg Psychiatry. 2013 Dec;84(12):1384-91.

68 Lam TC, Sahgal A, Lo SS, Chang EL. An update on radiation therapy for brain metastases. Linchuang Zhongliuxue Zazhi. 2017 Aug; 6(4):35.

69 Gondi V, Pugh SL, Tome WA, Caine C, Corn B, Kanner A, et al. Preservation of memory with conformal avoidance of the hippocampal neural stem-cell compartment during whole-brain radiotherapy for brain metastases (RTOG 0933): a phase II multi-institutional trial. J Clin Oncol. 2014 Dec;32(34): 3810-6.

70 Shaw AT, Yeap BY, Mino-Kenudson M, Digumarthy SR, Costa DB, Heist RS, et al. Clinical features and outcome of patients with non-small-cell lung cancer who harbor EML4-ALK. J Clin Oncol. 2009 Sep; 27(26):4247-53. 